\title{
Museum, audio
} description and tactile resources for visually impaired people: accessibility of Room Aldemir Martins at Art Museum (MAUC/ UFC)

Museu, audiodescrição e recursos táteis para pessoas com deficiência visual: acessibilidade da Sala Aldemir Martins do Museu de Arte (MAUC/ UFC)

Janaína Vieira Taillade ABUD (UFMG) janataillade@gmail.com

Geórgia Tath Lima de OLIVEIRA (UECE) georgia.tath@aluno.uece.br

Saulo Moreno ROCHA (MAUC-UFC) smr.museologo@ufc.br

Recebido em: 31 de jan. de 2021. Aceito em: 25 de ago. de 2021.

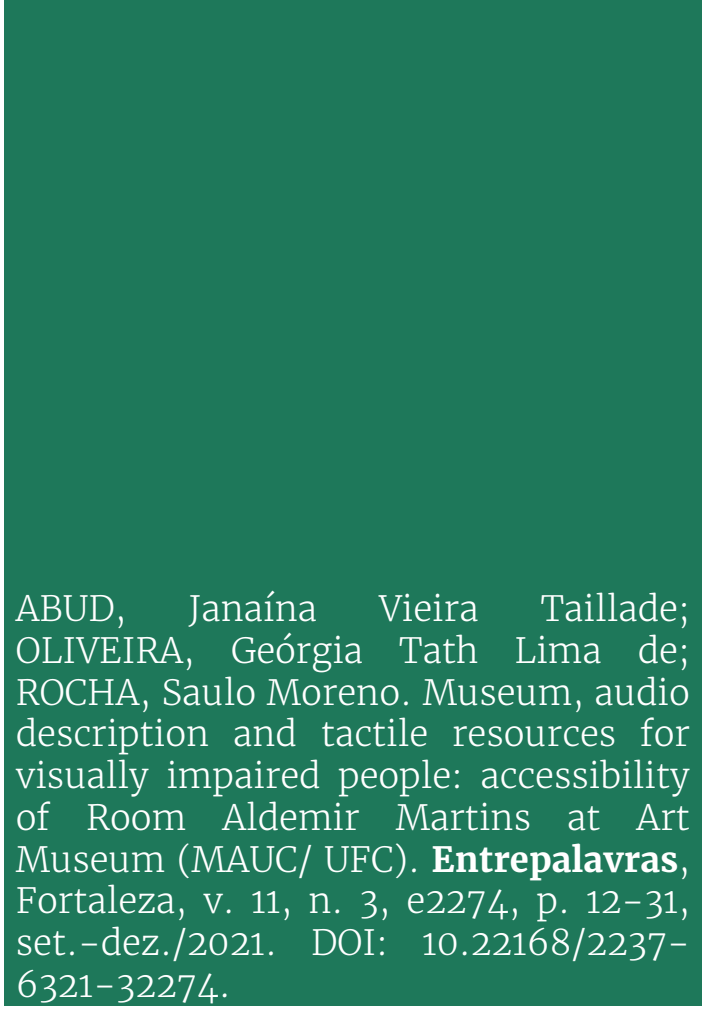

Abstract: This study aims to make accessible the paintings of Aldemir Martins, at Art Museum of Federal University of Ceará (MAUC) to blind and visually impaired people, focusing on the work of art Galo (1977). The research situates audio description (AD) as a form of Accessible Audiovisual Translation (AAVT) and tactile artwork as a translation of visual image into tactile language (DE COSTER; MUHLEIS, 2007; HOLLAND, 2009). Our work is based on the framework of Systemic Functional Linguistics (SFL) to provide an understanding of the piece of art (O'TOOLE, 2011). The theoretical and methodological frameworks of action research were used to create the $\mathrm{AD}$ and tactile artwork, harmonically (BARBIER, 2007). Computer-aided technologies for automatic or semi-automatic translation of paintings into tactile language were used (CARFAGNI et al., 2012). The first procedure was analyzing the paintings using the aforementioned theoretical background and writing the audio descriptions. The second procedure was submitting the $\mathrm{AD}$ to the group of participants, including blind audio description consultants, to ensure that the tactile pieces of art were made in 
harmony with the AD. The third step was submitting both resources to a reception test. As a result, it was possible to establish preliminary criteria for $\mathrm{AD}$ and tactile artwork. The results also show that one completes the other regarding accessibility.

Keywords: Tactile artwork. Haptic exploration. Accessible Audiovisual Translation. Audio description.

Resumo: Este estudo objetiva tornar acessíveis para as Pessoas com Deficiência Visual as pinturas de Aldemir Martins, no Museu de Arte da Universidade Federal do Ceará (MAUC), com foco na obra Galo (1977). A pesquisa situa a Audiodescrição como uma forma de Tradução Audiovisual Acessível (TAVa) e a obra de arte tátil como a tradução da imagem visual em uma linguagem tátil (DE COSTER; MÜHLEIS, 2007; HOLLAND, 2009). Nosso trabalho toma como base a perspectiva da Linguística SistêmicoFuncional (LSF) para proporcionar uma compreensão da obra de arte (O'TOOLE, 2011). Como arcabouço teórico-metodológico, foi usada a Pesquisa-Ação para elaborar a AD e a peça tátil de forma harmônica (BARBIER, 2007). Foram usadas tecnologias assistidas por computador, com a finalidade de realizar a tradução automática e semiautomática das pinturas em linguagem tátil (CARFAGNI et al., 2012). O primeiro procedimento foi analisar as pinturas usando a base teórica citada e escrever as audiodescrições. O segundo procedimento foi submeter a $\mathrm{AD}$ ao grupo de participantes, que incluiu consultores PcDVs em audiodescrição, garantindo que as peças táteis estejam em harmonia com as ADs. O terceiro passo foi um estudo inicial de recepção. Como resultado, foi possível estabelecer os critérios preliminares para $\mathrm{AD}$ e peças táteis. Os resultados também demonstraram a complementaridade entre as duas ferramentas de acessibilidade.

Palavras-chave: Obra de arte tátil. Exploração tátil. Tradução Audiovisual Acessível. Audiodescrição.

\section{Introduction}

Usually, museums are accessible mainly through vision. Artworks - whether they are 3D design, scientific or historical objects, photographs, paintings, or sculpture - are rarely available to touch. This reality makes it impossible for blind and visually impaired people to enjoy art. Previous studies point out that there are few cases of paintings "translated" into tactile representations, because of the lack of scientific criteria and methods about it. The same happens with audio description of artworks which have not been much explored in research. Sensitive to the rightful demand of this public, our research proposes to provide accessibility to the Room Aldemir Martins, which exhibits 22 works, including acrylic paintings, engravings, and drawings, at the Art Museum of Federal University of Ceará (MAUC). This article focuses specifically on the accessibility of one work, namely Galo (1977).

In this research, two main strategies were chosen to make Aldemir Martins works of art accessible: Audio Description (AD) and tactile artwork. The study is part of the Assistive Technology Project 
V. 11 (3)

$12-31$

set-dez

2021 of Federal University of Ceará (in Portuguese, Projeto de Tecnologia Assistiva da Universidade Federal do Ceará - UFC). The research also gathers the Digital Workshop of the Architecture, Urbanism and Design Department (in Portuguese, Oficina Digital do Departamento de Arquitetura e Urbanismo e Design - DAUD) and the Art Museum of UFC (MAUC). It is also conducted in cooperation with the Subtitling and Audio Description Group (in Portuguese, Grupo Legendagem e Audiodescrição - LEAD) of State University of Ceará (in Portuguese, Universidade Estadual do Ceará - UECE).

Therefore, this work understands audio description as a way to translate visual elements into words with the purpose of making an artwork accessible to blind and visually impaired people. Consequently, our study falls within the field of Translation Studies (TS), more particularly in the studies of Accessible Audiovisual Translation (AAVT). In addition, tactile artworks are understood as "translations of visual images into tactile language". This concept emphasizes that tactile pieces are not expected and are not able to be "exact relief reproductions of visual images" (CARFAGNI et al., 2012, p. 262).

Few publications address audio description of art. The first ones are from Europe: De Coster and Mühleis (2007) and Holland (2009). De Coster and Mühleis (2007) highlight that audio description of art translates into words the "visual sensation" of the work described. These visual sensations refer to the interaction between the sense of sight and the other senses, especially touch. They based their definition on what they call "visual intensity" and "narrative" of a work of art, which are related to artistic complexity and the consequent degree of difficulty in the translation process. Thus, the authors divide visual signs into clear ones and ambivalent ones.

Holland (2009) questions if audio description of art must focus on describing "what you see", because, according to him, the meaning of art is situated far beyond physical aspects. One of his contributions is also reflecting about the impossibility of impartiality in describing art. The reason is that, for him, one cannot separate seeing from understanding. Based on that, he refutes the recommendation for audio describers to be objective, instead advising them to know as much as possible about the art they describe and to engage with the artistic team. Holland also defends that our senses are interdependent, which means that experience of sight is affected by other senses and vice versa. 
O'Toole (2011) suggests a model to appreciate works of art, based on the framework of Systemic Functional Linguistics (SFL). Although he does not address audio description, in this article, we understand his model as a guide to look through the paintings. The author takes up the three functions of language, according to SFL, and adapts them to art, in order to provide a shared language while speaking of art.

Mayer (2016) addresses construction and referencing of color by people with congenital blindness. She conducts an experiment, which involves audio description of artwork colors. As part of her findings, she emphasizes that hearing the $\mathrm{AD}$ is complementary to touching the piece of art. According to her, sensing by touch allows blind and visually impaired people to organize the scenery. Her statement not only gives us clues to understand the role of tactile pieces of art, but also guides us to consider as complementary the verbal translation of visual elements (AD) and their tactile translation.

In this respect, Carfagni et al. (2012) study tactile exploration of art. For them, blind people learn about their environment through the manipulation of objects. Consequently, they propose a methodology to develop tactile artwork which is partially used in the present work.

Based on these assumptions and on this theoretical framework, this research tries to find answers to the following questions: 1) Which criteria could guide the audio descriptions of Aldemir Martins' painting? 2) How could audio description and tactile artwork of Aldemir Martins' paintings be aligned? 3) How is the impact of these two resources of accessibility combined in the reception of Aldemir Martins' artwork?

This paper is composed of eight sections including this introduction. The second one establishes the theoretical basis of the study. The third one contextualizes the artistic work of Aldemir Martins, whose artworks are used as corpus. The fourth one describes the methodology. The fifth and sixth examine, respectively, the preliminary findings and discussion. The seventh section exposes the conclusion and is followed by the references.

\section{Theoretical framework}

This section is divided into three parts. The first part presents the general framework of the Accessible Audiovisual Translation (AAVT) field, as well as the specific contribution by Holland and De Coster 
V. 11 (3)

12-31

set-dez

2021

and Mühleis with respect to audio description of art. The second part focuses on the work of O'Toole. The third part deals with the theoretical bases adopted for tactile artwork.

Accessible Audiovisual Translation and audio description of art

Audio description is considered a type of translation according to Jakobson's (1959/2010) classification. The author distinguishes three types of translation. In his definition, audio description of art falls under the concept of intersemiotic translation (or transmutation), since he defines it as "an interpretation of verbal signs by means of signs of nonverbal signs systems" (JAKOBSON, 1959/2000), and since Plaza (2013) expands this concept to the inverse, i.e., a translation of nonverbal signs to verbal ones.

Furthermore, audio description falls within the field of Audiovisual Translation (AVT) because, as explained by Franco and Araújo (2011), this type of translation encompasses all those which happen in a space that includes an acoustic signal and a visual one, regardless of if on stage or transmitted through a screen. Therefore, AVT includes, for instance, interlingual subtitling, dubbing and voiceover. Being more specific, audio description is a type of Accessible Audiovisual Translation (AAVT) as defined by Jiménez Hurtado (2010) as a form of AVT that benefits disabled people. In this last concept, $\mathrm{AD}$ as well as Subtitle for the Deaf and Hard of Hearing (SDHH) are included.

Regarding audio description of artwork, the first authors to undertake the task of examining its features are De Coster and Mühleis (2007) and Holland (2009). This study uses both as a starting point of the investigation. As commented before, De Coster and Mühleis (2007, p. 189) give an interesting definition of audio description concerning art. For them, it is "a means of translating the visual impression of an object into words". When the authors use the terms "visual impression", they are referring to the intersensorial aspect of this kind of translation. Therefore, they are mainly talking about bringing tactile sensations to the description. For them, the more a work of art is intersensorial and rich in narratives, the more it has "visual intensity" (DE COSTER; MÜHLEIS, 2007, p. 191). This visual intensity makes describing it more complex, because of "the tactile sensations that need to be put into words" (DE COSTER; MÜHLEIS, 2007, p. 191). 
Then, De Coster and Mühleis (2007) divide visual signs into clear and ambivalent ones. In this article, we consider that clear signs are rare in art, because they need, according to the authors, to be directly identified and perfectly translatable into words. Unlike these clear signs, ambivalent ones "communicate different levels of meaning" (DE COSTER; MÜHLEIS, 2007, p. 192) and can be put into words, although with difficulty, "especially if the visual effects cannot be represented through other fields of sensual imagination (such as touch or hearing)" (DE COSTER; MÜHLEIS, 2007, p. 192). The authors advise that, if there is ambivalence, verbal language must give this idea. They also state that museums which offer art by tactile exploration are not exempt from accompanying it with $\mathrm{AD}$. In this case, audio description provides visual guidance, "a form of interplay between the visual image and the tactile sensation that needs to be put into words" (DE COSTER; MÜHLEIS, 2007, p. 191).

Holland (2009) addresses some important issues for AD of art. He starts with a provocation: what really matters in an artistic experience and deserves to be described? "By describing the physical characteristics of a work of art, are we really describing the art?" (HOLLAND, 2009, p. 171). Taking this as a starting point, he advocates that audio description could not be neutral. Instead, in his point of view, $\mathrm{AD}$ asks for an immersion in the artistic experience and needs contact with creative people, the artists themselves. He defends "placing the describer nearer the creative process" (HOLLAND, 2009, p. 173) and making the describer as expert as he or she could be about the work of art to describe. Holland emphasizes his disagreement with the standard which defends "say what you see" to audio describers. For him, "this phrase is a nonsense which attempts erroneously to divorce 'seeing' from 'understanding', and that in this process of understanding the other senses are involved alongside sight" (HOLLAND, 2009, p. 184).

Then, audio describing art is a question of interpreting it. "This means integrating the description so that it becomes part of the artistic experience" (HOLLAND, 2009, p. 184). The purpose of AD should be, according to Holland (2009, p. 184), "getting to the heart of a work of art", as well as recreating the original experience, "bringing it [the artwork] to life" (HOLLAND, 2009, p. 184). To reach this goal, Holland points out that studies in psychology explain the interdependence of senses. Vision, touch, and hearing influence each other, and artists use this constantly. For example, he argues that one limitation of sight is not giving the sense of third dimension like touch does. 
V. 11 (3)

12-31

set-dez

2021
A guidance to look at works of art

Following Holland's (2009) recommendation for describers to deepen their comprehension of artworks, this research chooses the contribution of O'Toole (2011). The author is in line with the Systemic Functional Linguistics (SFL) framework. Therefore, he proposes a "shared language" to speak about art, based on the three functions of language according to SFL. As other pieces of communications, art has these three functions: interpersonal - "to engage our attention and interest"; experiential - "to convey some information about reality"; and textual - "to structure these into a coherent textual form" (O'TOOLE, 2011, p. 10). O'Toole adapted these concepts to art and renamed the functions as modal, representational, and compositional, respectively.

In O'Toole's way of thinking, a shared language is necessary when speaking about art, because appreciating art involves interpretation and subjectivity. This makes it so complex to transform visual impressions into words, because these impressions seem so personal. Offering his model, he wants to allow us to put into words how the public usually perceives the paintings, based on the knowledge of the strategies adopted by artists, according to the "grammar of painting" (O'TOOLE, 2011, p. 11). At the same time, he intends to make us escape from focusing merely on historical, technical, psychological, or mythological aspects of paintings.

To follow O'Toole's (2011) explanation, it is important to understand some concepts he uses. The author divides paintings into levels of analysis: work (the entire painting), episodes (meaningful group of human figures or objects), figures (figures or objects), and members (details that contribute to the meaning). It is also essential to know that there is no compulsory order when analyzing art through functions, but just suggestions. Another notable point is that functions are integrated and interconnected in art and every type of language. They work together, being separated just for the purpose of analysis.

O'Toole (2011) defends that modal function is the best way to start a conversation about art. He argues that the first thing that catches attention is what engages the viewer, in terms of attention, thoughts and emotions. This engagement is made by modal function. The author states that "the systems of this function are virtually universal. One might say that they provide the 'baseline' for more individual conceptions and 
flights of fancy" (O'TOOLE, 2011, p. 11). Amongst the modal strategies, he situates rhythm, gaze, framing, light, and perspective. For instance, one strategy could be a direct gaze of one or more painted persons in the direction of viewers. Rhythm corresponds to a perception of movement, be it in the curves of an attire or in the positions of a body. Light in turn could attract the viewer's look to some specific point.

The representational function is related to "what the painting actually depicts" (O'TOOLE, 2011, p. 16). O'Toole (2011) notices that it is usually the point everyone wants to reach, but it is not so simple as it appears to be. An unfamiliar landscape, a historical or mythological event, or abstract paintings without title are some examples of difficulties. The author points to some guidelines to follow, mainly the representation of narratives (based on figures' actions), portrayals, and symbolisms. When describing representational function, he suggests beginning with figures, passing through episodes, and ending with the entire work.

The compositional function consists of how forms are arranged within the pictorial space. It is linked to positions and connections of figures, lines, rhythms, and forms. In this topic, O'Toole lists features as: proportion, position in the work or episode, cohesion (parallel, contrast, rhythm), and reference. The author also explains the influence of Gestalt in this function. Gestalt means that "we always have an overall perception of forms and objects and that when we focus on their parts, we perceive them in relation to the whole" (O'TOOLE, 2011, p. 29). This vision of the whole influences our sense of sight and seems to be important too in tactile exploration, which leads us to address tactile artwork.

Tactile artwork

Carfagni et al. (2012) base their study about tactile artwork on two main assumptions. The first one states that tactile exploration is a means for blind people to learn about their surroundings. They call it "haptic exploration (from Greek haptomai, grab hold, touch with care)" (CARFAGNI et al., 2012, p. 261). The second presupposition points out that this process of tactile exploration helps create a mental image in two steps. One step consists of a quick and global exploration, focused on having an idea of the whole. The other searches for details to place them in context. 
V. 11 (3)

$12-31$

set-dez

2021

Carfagni et al. (2012) observe that most accessibility initiatives work with 3D exact reproductions, which are more appropriate to sculpture accessibility. They also identify the scarcity in tactile translations related to paintings. They link it to the lack of scientific criteria and methods for $2 \mathrm{D}$ translation. They also connect it to the cost of time and money, since the methods proposed usually invest on pieces handmade by artists.

Despite these limitations, the authors reference some important previous research. These studies have established tactile diagrams as a possible translation in two dimensions. Diagrams represent the forms by relief lines on a flat surface and use textures to distinguish one form from another. Tactile diagrams provide the possibility of highlighting a detail by making a second diagram with more details on a separate surface. Another option is bas-relief: a flat surface which receives a slightly thicker relief representing the figures. The findings of these studies include criteria about thickness and closeness of the relief lines; size of explorable objects; fragmentation of complex images; and necessity of verbal description.

Carfagni et al. (2012) carried out a reception test with a panel of blind people, in contact with tactile diagrams using textured patterns and bas-relief like representations. Half of the participants had Congenital Blindness (C.B.) and the other half had Acquired Blindness (A.B.). As a result, they found that both audiences need detailed verbal description to understand the models. Bas-relief has by far the most "readability" (CARFAGNI et al., 2012, p. 269), which means they are easy and enjoyable to read. Concerning details and comprehension of shapes, the reasons for the bas-relief preference are divergent. Participants with A.B. prefer them because $50 \%$ perceive the details better; and 34\% comprehend the shapes better. Answers of participants with C.B. in turn show that $75 \%$ have better perception of shapes and $6 \%$ better detail perception. All these results were considered in the preparation of the tactile artwork of Aldemir Martins in the present study.

Having set out this theoretical basis, the next section deals with the artistic context of the corpus.

\section{Aldemir Martins: the artist and his work}

Aldemir Martins was a painter, illustrator, engraver, sculptor, and artist from Ceará, born in Ingazeiras, a district in the municipality 
of Aurora, in the Cariri Valley region, in 1922. As a child, he already manifested his first creative impulses, using resources such as pieces of roofing tiles, coal, and other simple and rudimentary means to express himself (TARDIN, 2017, p. 17). Throughout his life, he achieved vast recognition, being among the most representative artists of his generation, being enshrined in the national and international artistic scenes with countless expositions and inclusion in the art market.

He began his career in the Army, where he worked between 1941 and 1945. In acknowledgement of his technical quality, he was known as "Painting Private", winning awards and recognition with his productions. Aldemir participated in the creation of the Fine Arts Cultural Center (Centro Cultural de Belas Artes - CCBA), an initiative by Mário Barata along with other local artists. CCBA, soon after its conception, created the April Salon - until now one of the oldest and most prestigious Brazilian artistic salons - and was a base for the foundation of the Society of Visual Artists of Ceará (Sociedade Cearense de Artistas Plásticos - SCAP), institution which renovated the art in Ceará (FIRMEZA, 1983) and boosted the artistic scene in Fortaleza, projecting names such as Antônio Bandeira, Inimá de Paula and Aldemir himself.

With few opportunities in Ceará and aiming at more auspicious career horizons, Aldemir moved to Rio de Janeiro, where his friend Antônio Bandeira lived. After a brief stay in the city, in 1945 he moved to São Paulo, there achieving significant work in press, in the art circuit, and other institutions, integrating the artistic and intellectual universe of the city. In 1949, he took a course in Art History at the São Paulo Museum of Art (Museu de Arte de São Paulo - MASP), with Pietro Bardi, and started working as an instructor at the institution's expositions.

His work is profoundly marked by symbols and images associated to the Brazilian Northeast and Ceará. Connections to his home state spread beyond artistic productions, reaching the plane of interpersonal relationships, given the support and incentive he provided new artists, the friendships he always cultivated and lasting contact with the local artistic scene. The Federal University of Ceará awarded him the Medal for Cultural Merit in 1973, and the Art Museum of UFC (MAUC) has, since 1979, an individual room dedicated to his production in a permanent exposition.

MAUC's Aldemir Martins Collection was formed through donations by artist and art historian Nilo de Brito Firmeza, known as Estrigas, founder of Minimuseum Firmeza with his wife, Nice Firmeza. 
V. 11 (3)

$12-31$

set-dez

2021

The couple, who had also been part of SCAP, had a strong friendship bond with Aldemir and contributed to perpetuate his memory at institutions dedicated to the memory of Arts in Ceará.

Restless and bold artist Aldemir Martins gained notability for his remarkable strokes and the vibrant colors of his paintings. He eternalized on canvases, engravings and sculptures an imagination of the Brazilian Northeast populated by cangaceiros, lacemakers, and Blessed people, as well as the region's flora and fauna. According to Maria Eliene Magalhães (2015, p. 103, our translation), Aldemir:

By thinking the country in its regional diversities, although focusing on his home state, he gave new forms to interpretations constituted about the region. Even regarding a space marked by climatic and natural difficulties, he highlights the qualities of people, fauna and flora, aiming to deconstruct the scenario of hopelessness, hunger and poverty historically constructed not only about the northeast region, but about the less populated areas of the country. More than inserting them in the nation's imagination, he presents them as formative of an us-identity, transforming into symbols the social structures with which we identify and, as last instance, define us as individuals. ${ }^{1}$

Without being locked into limiting regionalism, he expanded the Brazilian cultural repertoire, contributing to other ways of imagining and conceiving traditional images. His disconcerting geometries and plural themes, as well as his participation as illustrator of telenovelas and books, propelled him beyond art circuits, expanding the impact and popularity of his work, which still impacts and inspires new audiences.

After presentation of Aldemir Martins and his work, we proceed in presenting the methodology.

\section{Methodology}

In this qualitative approach study (MINAYO et al., 2002), we used as theoretical and methodological framework the action research method, which, according to Barbier (2007), interweaves thought and action through a real-life problem. As a real-life problem, we

\footnotetext{
${ }^{1}$ Source-text (our translation): Ao pensar o país em suas diversidades regionais, embora se concentrando em seu Estado natal, deu feições novas às interpretações que se constituíam sobre a região. Mesmo tratando de um espaço marcado pelas dificuldades climáticas e naturais, ressalta as qualidades do povo, da fauna e da flora, visando desconstruir o cenário de desesperança, fome e miséria historicamente construído não apenas sobre a região nordeste, mas sobre as áreas menos povoadas do país. Mais do que inseri-las no imaginário da nação, apresenta-as como constituintes de uma identidade-nós, transformando em signos as estruturas sociais com as quais nos identificamos e em última instância, que nos define enquanto indivíduos.
} 
considered the need to make visual artworks - paintings - accessible, so that visually impaired people can experience an artwork similarly to a seeing person (DEWEY, 2008), thus developing ethical and aesthetic values related to art enjoyment, necessary to constitute human identity.

Action research consists of a methodological proposal stemming from the needs of a specific social group, instead of the researcher's interest. In this investigation, it stems from blind people's need to access visual artworks, as a way to participate in contemporary artistic and cultural activities, enabling one manner of inclusion for that social group, and from the desire of the management at the Educational Department at MAUC to make their collection accessible for a blind audience.

The corpus selected for this research was the painting Galo (1977) (Figure 1), by artist Aldemir Martins, due to the fact that it is one of the works shown at room Aldemir Martins at MAUC, locus of this investigation.

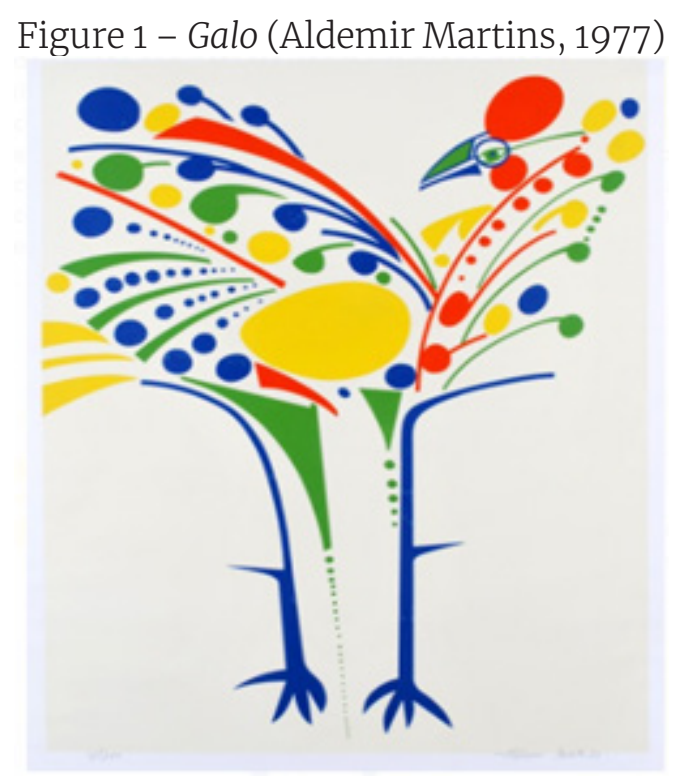

Source: MAUC Collection.

We revisit here the starting questions, presented in the introduction, in order to better describe procedures we used to answer them. 1) Which criteria could guide the audio descriptions of Aldemir Martins' painting? 2) How could audio description and tactile artwork of Aldemir Martins' paintings be aligned? 3) How is the impact of these two resources of accessibility combined in the reception of Aldemir Martins' artwork? 
V. 11 (3)

$12-31$

set-dez

2021

Initially, we propose AD training for artworks - paintings aimed at a group constituted by members of the Educational Department at MAUC, members of DAUD, members of LEAD and blind consultants. Throughout that training, we used some artworks by Aldemir Martins, including the one represented by Figure 1.

To carry out that training, we promoted 30 synchronous remote meetings between June and December 2020, via Meet $^{2}$, a resource available at Google. These meetings, intending to present the theoretical basis that grounds this study, took place twice per week, lasting 2 hours each, with a full course load of 60 hours.

In addition to synchronous remote meetings, participants also did asynchronous remote tasks. To this end, interlocutors were organized in 3 groups, constituted by audio descriptors in training, blind consultants, and course facilitators, one in each group. These groups received images to analyze through WhatsApp. Using that app, interlocutors reflected about these steps: image analysis; creation of initial proposals for $\mathrm{AD}$ scripts for those images; sharing the initial script proposals in the group; discussion about the initial proposals; alteration of the initial scripts based on the discussions; sharing the modified scripts with all research participants during synchronous meetings.

Consultants had an active role in each step, because, in this study, we consider the presence of those participants indispensable to the creation of $\mathrm{AD}$ scripts, since, if the product is specifically aimed at that audience, there would be no reason to overlook their protagonism during its creation, corroborating disabled people's motto: "Nothing about us without us". This entire methodological design, as well as the development of the aforementioned steps, was carefully monitored by the researchers.

This material, both scripts and discussions, started to act as a guide for the creation of the painting's tactile piece, so that there was harmony between the two translation methods (CARFAGNI et al., 2012).

Regarding the tactile artwork, it is printed on MDF wood, through computer-controlled machinery, which uses laser to cut the MDF board. Depending on the depth of the image to be reproduced in tactile artwork, several MDF layers are superposed so that, as they are carved

\footnotetext{
${ }^{2}$ All communication during the training period, including training lessons, took place through Information and Communication Technologies due to the current context of the pandemic and subsequent social isolation.
} 
by the laser-cutting process, they can transmit the approximate notion of depth represented in the painting (CAVALCANTE et al., unpublished). In addition to depth, other details are shown in the tactile artwork, especially shapes and, in some cases, dimensions. Figure 2 shows an example of tactile artwork, corresponding to the painting Galo (1977).

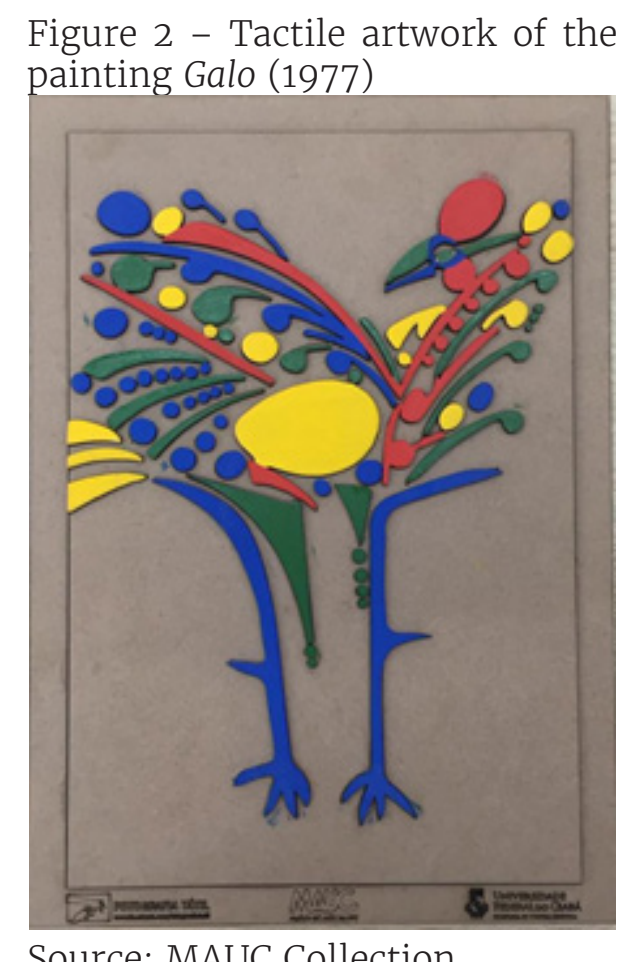

Source: MAUC Collection.

Having described the methodology, in the next section, we proceed in presenting the results.

\section{Results}

Throughout the $\mathrm{AD}$ training, it was possible to obtain, through the interlocutors' speech during image analysis, creation of $\mathrm{AD}$ scripts and group discussions, data that pointed to criteria to use and replicate during the creation of $\mathrm{AD}$ scripts, which are subsequently discussed.

Description from the whole to the parts. This condition favors mental construction of the image, contextualization of the artwork and clarification of perspectives and planes, corresponding to O'Toole's (2011) affirmation about compositional function and the attempt to construct a perfect whole (Gestalt), through its parts, using the AD script.

Description of colors. This criterion enabled blind people to link colors, when possible, to shapes and volumes, as well as haptic sensations - temperature, texture -, which helps harmonize the $\mathrm{AD}$ 
v. $11(3)$

12-31

set-dez

2021

and tactile artwork, proving the relevance and need for intersensorial translation, as defended by De Coster and Mühleis (2007) and Holland (2009). Mayer (2016) also emphasizes that colors need to be included in $\mathrm{AD}$ scripts for artworks and that, if possible, the $\mathrm{AD}$ experience should be complemented by touch, enabling better organization by the blind audience of the scene being described.

Description of shapes and lines. This criterion also enabled blind people to link colors, volumes and rhythm, according to O'Toole's (2011) compositional function, when the AD for the painting Galo (1977) presented intersensorial elements, as suggested by De Coster and Mühleis (2007) and Holland (2009), through comparisons with other elements from blind people's real world.

\section{Description of actions detailing figures in the spotlight and} obscurity. By highlighting the elements used by the artist to get the spectator's attention on the artwork, according to O'Toole's (2011) modal function, this criterion enabled audio descriptors to explore and emphasize details in Galo (1977), such as the rooster's figure, its colors and gestures, so that the blind audience could experience better interaction with the piece.

Description of framing and positions of figures in the spotlight and obscurity (lighting, scale, and proportion). As in the previous criterion, framing, spotlight and obscurity are also resources present in O'Toole's (2011) modal function, i.e., must be described in order to enable blind people to enter the world created by the artist in the artwork. In the painting Galo (1977), the rooster's position, with its body in profile and the head turned back, as if looking at its own body, engage the spectator in an attempt to understand the meaning of that movement, as well as hone certain sensations, feelings and thoughts about the universe pictured.

Description of verbal and numerical elements (date and signature, dimensions, technique). De Coster and Mühleis (2007) suggest exploring certain information on the artwork, such as verbal and numerical elements, aspects that weren't listed by O'Toole (2011) or Holland (2009), but that helped, in this research, to socially and temporally contextualize the artwork; this information was requested by the consultants themselves, to enable the expansion of their artistic and cultural range.

Description of the art emphasizing author's style and technique. Another type of information requested by consultants in the 
$\mathrm{AD}$ was emphasis on the artist's style and technique, which function as a kind of identity and enable the recognition of other works by the same artist. Regarding Aldemir Martins, it was suggested that AD should highlight the vibrant, strong colors he used, as well as the marked, occasionally visible brushstrokes, acting as an identity trace and recognition of his work.

Use of evaluative language or terms expressing affection, judgement, appreciation, modalization and gradation. In the consultants' understanding, $\mathrm{AD}$ which presents evaluative (subjective) language may confer to the artwork the expected emotion when interacting with Art, providing a truly artistic experience. This corroborates Holland's (2009) thought that states it is necessary to attempt to reach the heart of an artwork through $\mathrm{AD}$, instead of only describing physical elements.

Use of technical language about painting. This criterion represented many doubts that we hope to answer with future research about this theme.

Whenever possible, visit artworks before creating the final AD. This criterion enabled consultants to experiment listening to an $\mathrm{AD}$ in front of the artwork at the museum, feeling the space, the acoustics, the time it would take to complete the exposition, allowing them to suggest further alterations in scripts to turn that visit into an experience actually accessible for other blind people, giving new meaning to a space that, since its origin, has been denied to them.

Finally, after the AD training, the course facilitators, some audio descriptors in training and one of the blind consultants that participated in the study visited room Aldemir Martins at MAUC to test the modified AD script of the painting Galo (1977) and, only after that visit, the final script was created, which is shown on Table 1. 


\section{V. $11(3)$}

$12-31$

set-dez

2021

Table 1 - Final AD script of the artwork Galo (1977)

Galo. 1977. Color silkscreen on paper. 70 centimeters of height by 50 centimeters of width. The colorful and vertical engraving shows a rooster, in all its magnificence and exuberance. It is standing with its body in semi-profile to the right. However, its face is in profile to the left, as if turning back in relation to the body. The animal is painted in blue, red, yellow, and green on a uniform white background. The strokes are geometrical and minimalist. Everything is simply suggested by the junction of geometric shapes: dots, circles, lines, triangles, and ellipses. Thus are the animal's silhouette, face, legs, and feet. Through the daintiness of the shapes, the representation shows a majestic rooster displaying its beauty as if opening its exuberant, colorful wings. Its face shows only one of the eyes, which is green, expressive, and seems to gaze upon the spectator. Its beak is green on top and blue underneath. Its comb and wattle are represented by two oval, red shapes. The feathering on the thighs, located parallel to the legs, is represented by two inverted green triangles. From one apex of each triangle, descends a line of points that decrease in size until near the rooster's feet. Its long, blue legs begin in the half of the canvas and reach the bottom. They have sharp spurs and feet with separated toes. The direction of the geometrical shapes suggests movement, giving the impression that, in the effort to seem impressive, the rooster opens its wings so widely that it messes its feathers. A large yellow ellipse in the center of the canvas seems to represent its chest. Next to it, the neck is suggested rising in two curved lines, one red and the other green, filled with red dots aligned in crescent sizes, that reach the base of the head. On the bottom right corner is Aldemir Martins' signature. ${ }^{3}$

Source: Created based on contributions by the participants of the AD training. Our translation.

In the next section, we undertake the discussion of our results.

\section{Discussion}

In this study, we sought to answer three questions: 1) Which criteria could guide the audio descriptions of Aldemir Martins' painting? 2) How could audio description and tactile artwork of Aldemir Martins' paintings be aligned? 3) How is the impact of these two resources of accessibility combined in the reception of Aldemir Martins' artwork?

\footnotetext{
3 Source-text (our translation): Galo. 1977. Serigrafia a cores sobre papel. 70 centímetros de altura por 50 centímetros de largura. A gravura colorida e vertical mostra um galo, em toda sua imponência e exuberância. Ele está em pé com o corpo em semiperfil para a direita. No entanto, o rosto encontrase em perfil para a esquerda, como se estivesse se voltando para trás em relação ao corpo. O animal é pintado nas cores azul, vermelho, amarelo e verde sobre um fundo branco uniforme. Os traços são geométricos e minimalistas. Tudo é apenas sugerido pela junção de formas geométricas: pontos, círculos, linhas, triângulos e elipses. Assim são a silhueta, a face, as pernas e os pés do animal. Pela delicadeza das formas, a representação ilustra um galo majestoso que exibe sua beleza como se estivesse abrindo suas exuberantes asas coloridas. O rosto mostra só um dos olhos que é verde, expressivo e parece fitar o espectador. Seu bico tem a parte de cima verde e a de baixo, azul. A crista e a barbela do galo são representadas por duas formas ovaladas e vermelhas. A plumagem das coxas, localizada paralelamente em relação às pernas, é representada por dois triângulos verdes invertidos. De um dos vértices de cada triângulo, desce uma fileira de pontos que vão diminuindo de tamanho até chegar perto dos pés do galo. Suas pernas compridas e azuis vão desde a metade até parte inferior da tela. Elas possuem afiados esporões e pés com dedos separados. A direção das formas geométricas sugere movimento, dando a sensação de que, no esforço de se mostrar imponente, o galo abre tanto as asas a ponto de desarrumar as penas. Uma grande elipse amarela no centro da tela parece representar seu peito. Próximo dele, adivinha-se o pescoço subindo em duas linhas curvas, uma vermelha e a outra verde, preenchidas por círculos vermelhos alinhados em tamanhos crescentes, que vão até a base da cabeça. No canto inferior direito, está a assinatura de Aldemir Martins.
} 
Regarding the first question, we presented ten criteria that emerged from the methodological design used to develop this investigation, which are: 1) Description from the whole to the parts; 2) Description of colors; 3) Description of shapes and lines; 4) Description of actions detailing figures in the spotlight and obscurity; 5) Description of framing and positions of figures in the spotlight and obscurity (lighting, scale, and proportion); 6) Description of verbal and numerical elements (date and signature, dimensions, technique); 7) Description of the art emphasizing author's style and technique; 8) Use of evaluative language or terms expressing affection, judgement, appreciation, modalization and gradation; 9) Use of technical language about painting; 10) Whenever possible, visit artworks before creating the final $\mathrm{AD}$. The criterion number 9 was the only one not completely understood, although it was mentioned by consultants as necessary to the $\mathrm{AD}$ script, but still requires further study and discussion.

Concerning the second question, the $\mathrm{AD}$ and the tactile artwork consist of distinct types of translation of visual elements, in this case, the painting Galo (1977). In this sense, to align the AD script that should be heard while the blind person touches the tactile piece, their construction process must take place in tandem. This coordinated process doesn't necessarily mean it has to be simultaneous, since what can be said in the AD script isn't always possible to represent on the tactile artwork, due to the physical limitations imposed by the material of which that piece is made, MDF wood. That happens because an alteration can be made more easily in a text, in this case, the $\mathrm{AD}$ script, than in a piece of wood after it has been cut. For that reason, the AD script is constructed considering the existence of a tactile artwork that can be touched, complementing the blind person's aesthetic experience.

As for the last question, the reception of Aldemir Martins' artwork, using the AD script and the tactile piece for the painting Galo (1977), was restricted to the consultants who participated in the study. However, it has been revealed that combining the two resources, despite being experiences of different natures, enables the blind person to experience aesthetic enjoyment in a space previously not imagined for that audience. It is also important to emphasize that having an $\mathrm{AD}$ script available to listen while touching a tactile artwork corresponding to the piece being described represents a possibility of entrance, in a more concrete manner, in the universe of visual arts, persistently denied to people with visual impairments. 
V. 11 (3)

12-31

set-dez

2021

\section{Conclusion}

The purpose of this research is to provide accessibility to the Room Aldemir Martins at the Art Museum of Federal University of Ceará (MAUC), focusing especially on the artwork called Galo (1977). To this end, the specific objectives of this article were three, as follows. The study investigated the criteria to guide the audio descriptions of Aldemir Martins' painting. It also attempted to determine how audio description and tactile artwork of Aldemir Martins' paintings could be aligned. In addition, the study aimed to determine what is the impact of these two resources of accessibility combined in the reception of Aldemir Martins' artwork.

The methodology included action research which was carried out in order to discuss and discover the criteria for $\mathrm{AD}$, as well as how to align it with tactile artwork. The audio descriptions and tactile pieces were submitted to reception research with visually impaired participants with the purpose of evaluating their impact. Both methodologies appear to be successful.

This study is inserted in Translation Studies (TS), specifically in the research about Accessible Audiovisual Translation (AAVT). As a theoretical framework, the article bases its reflection on the previous work addressing audio description of paintings (DE COSTER; MÜHLEIS, 2007; HOLLAND, 2009), appreciation of paintings (O'TOOLE, 2011) and development of tactile paintings (CARFAGNI et al., 2012).

This research found ten criteria to lead to an audio description which fulfills the specific demands of paintings, according to the authors mentioned. It also has adjusted tactile paintings to the $\mathrm{AD}$ resource. As a result of the reception test, the study pointed out that participants preferred long and detailed audio description. Furthermore, the participants commend the complementarity of $\mathrm{AD}$ and tactile piece of art, especially relating it to the comprehension of details.

As a limitation, we indicate that the system that tracks tactile exploration on the tactile piece could fail. The reason is that it tracks the light reflected by an adhesive put on a finger, but it could easily be mistaken with another brilliant object, like a ring. Despite this limitation, we hope that the findings could be used in future exhibitions.

Acknowledgement. The authors wish to thank Ana Carla Ponte Nóbrega for the translation to English of part of this article and for its entire proofreading. 


\section{References}

CARFAGNI, M.; FURFERI, R.; GOVERNI, L.; VOLPE, Y.; TENNIRELLI, G. Tactile representation of paintings: an early assessment of possible computer based strategies. In: IOANNIDES, M.; FRITSCH, D.; LEISSNER, J.; DAVIES, R.; REMONDINO, F.; CAFFO, R. (ed.). Progress in Cultural Heritage Preservation: EuroMed 2012. Berlin: Springer, 2012. p. 261-270. (Lecture Notes in Computer Science, v. 7616).

DE COSTER, K.; MÜHLEIS, V. Intersensorial translation: visual art made up by words. In: CINTAS, J. D.; ORERO, P.; REMAEL, A. Media for all: subtitling for the deaf, audio description, and sign language. Amsterdam/New York: Rodopi, 2007. p. 189-201.

FIRMEZA, N. de B. (Estrigas). A fase renovadora na arte cearense. Fortaleza: Edições Universidade Federal do Ceará, 1983.

FRANCO, E. P. C.; ARAÚJO, V. L. S. Questões terminológico-conceituais no campo da tradução audiovisual (TAV). Tradução em Revista, Rio de Janeiro, v. 11, 2011.

HOLLAND, A. Audio description in the theatre and the visual arts: images into words. In: CINTAS, J. D.; ANDERMAN, G. Audiovisual translation: language transfer on screen. Basingstoke/New York: Palgrave Macmillan, 2009. p. 170185.

JAKOBSON, R. On linguistic aspects of translation. In: VENUTI, L. (ed.). The Translation Studies Reader. London, New York: Routledge, 1959/2000. p. $113-118$

JIMÉNEZ HURTADO, C. Un corpus de cine: teoría y práctica de la audiodescripción. Granada: Tragacanto, 2010.

MAYER, F. A. A importância das coisas que não existem: construção e referenciação de conceitos de cor por pessoas com cegueira congênita. Belo Horizonte: Editora PUC Minas, 2018.

O'TOOLE, M. The language of displayed art. London: Routledge, 2011.

SANTOS, M. E. M. Traços de uma nação: Aldemir Martins do Ceará ao Brasil (1951-1982). 2015. 109 f. Dissertação (Mestrado Acadêmico em História) Programa de Pós-Graduação em História, Universidade Estadual do Ceará (UECE), Fortaleza, 2015.

TARDIN, M. Aldemir Martins. Fortaleza: Edições Demócrito Rocha, 2017. 